\title{
Resarch SQuare \\ Evidence for Natural Selection and Ethnic Diversity at the Adenylate cyclase 3 Gene Associated with Obesity and Type 2 Diabetes
}

Research article

Keywords:

Posted Date: October 5th, 2020

DOI: https://doi.org/10.21203/rs.3.rs-18469/v2

License: (9) This work is licensed under a Creative Commons Attribution 4.0 International License.

Read Full License 


\section{Abstract}

The authors have requested that this preprint be withdrawn due to erroneous posting.

\section{Full Text}

The authors have withdrawn this preprint from Research Square. 